\title{
ADVERSE DRUG INTERACTION BETWEEN ASPIRIN AND FUROSEMIDE: A CASE REPORT
}

\author{
GUNDETI KAVYA REDDY*, NISI GRACE KURIAKOSE
}

Department of Pharmacy Practice, TVM College of Pharmacy, Ballari, Karnataka, India. Email: satyashiva.ss@gmail.com

Received: 25 June 2019, Revised and Accepted: 30 August 2019

\begin{abstract}
Drug-drug interaction between two drugs leads to a serious adverse drug reaction which is an adverse drug interaction. A 60-year-old female patient came with complaints of chest pain since $6 \mathrm{pm}$ on the day of admission which is a burning type of pain and also a history of breathlessness. She was a known case of hypertension and diabetes mellitus since 5 years on medications, i.e. tablet atenolol-5 mg - $1-0$ - 0 , tablet amlodipine - $5 \mathrm{mg}$ - 1-0-0, and tablet metformin - $500 \mathrm{mg}-1-0-1$; the patient's appetite was reduced and sleep was disturbed. On examination, blood pressure was 120/100 mmHg, pulse rate: $80 \mathrm{bpm}$, Sp02: 94\% with room air, respiratory system: B/L coarse crepitation (+), and pallor (+) remaining systemic examination showing no any deformities. Laboratory reports show microcytic hypochromic with neutrophilia and thrombocytosis and ultrasonography (USG): B/L Grade I renal parenchymal disease. The patient treated with the following mentioned medication during his hospital stay. both the drugs injection calcium gluconate and asthalin nebulization were given on $3^{\text {rd }}$ day of admission. The patient diagnosed as chronic kidney disease in the middle of the treatment which was adverse reaction interaction between aspirin and furosemide.
\end{abstract}

Keywords: Hypertension, Diabetes mellitus, Microcytic, Hypochromic, Neutrophilia, Thrombocytosis, Renal parenchymal disease, Nephrotoxicity, Interactions.

(C) 2019 The Authors. Published by Innovare Academic Sciences Pvt Ltd. This is an open access article under the CC BY license (http://creativecommons. org/licenses/by/4. 0/) DOI: http://dx.doi.org/10.22159/ajpcr.2019.v12i10.34626

\section{INTRODUCTION}

Aspirin may reduce the diuretic effect of bumetanide, furosemide, or piretanide and reduce the venodilation produced by furosemide. The combination of aspirin and furosemide may increase the risk of acute renal failure and salicylate toxicity. The risk of ototoxicity with high doses of salicylates may theoretically be increased by loop diuretics [1]. Furosemide is a strong diuretic but a weaker antihypertensive than thiazides: Fall in blood pressure (BP) is entirely dependent on reduction in plasma volume and cardiac output (C.O). The natriuretic action lasting only 4-6 hours after the conventional morning dose is followed by compensatory increase in proximal tubular reabsorption of $\mathrm{Na}^{+}$. Intravenous furosemide causes a prompt increase in systemic venous capacitance and decreases left ventricular (LV) filling pressure, even before the saluretic response is apparent. This action also appears to be PG mediated and is responsible for the quick relief it affords in LV failure and pulmonary edema. Moreover, the high ceiling diuretics are more liable to cause fluid and electrolyte imbalance, weakness, and other side effects.

Aspirin is the first drug to be used in all cases; other drugs are added or substituted only when it fails or in severe cases. Aspirin is a weaker analgesic (had lower maximal efficacy) than morphine type drugs: aspirin $600 \mathrm{mg}$ codeine $60 \mathrm{mg}$. However, it effectively relieves inflammatory, tissue injury-related, connective tissue, and integumental pain but is relatively ineffective in severe visceral and ischemic pain. Anti-inflammatory action is exerted at high doses (3-6 g/day or $100 \mathrm{mg} / \mathrm{kg} /$ day). Aspirin has no direct effect on the heart or blood vessels in therapeutic doses. Larger doses increase cardiac output to meet the increased peripheral $\mathrm{O}_{2}$ demand and cause direct vasodilatation. Toxic doses depress vasomotor center: BP may fall. Because of increased cardiac work as well as $\mathrm{Na}^{+}$and water retention, congestive heart failure may be precipitated in patients with low cardiac reserve. The plasma $t^{1} / 2$ of aspirin as such is $15-20 \mathrm{~min}$, but taken together with that of released salicylic acid, it is 3-5 hours. However, $\mathrm{t}^{1} \frac{1}{2}$ of anti-inflammatory doses may be $8-12$ hours while that during poisoning may be as high as 30 hours.
Adverse effects of non-steroidal anti-inflammatory drugs (NSAIDs)

a) Renal: $\mathrm{Na}^{+}$and water retention, chronic renal failure, nephropathy, and papillary necrosis (rare)

b) Hematological bleeding, thrombocytopenia, hemolytic anemia, and agranulocytosis [2].

\section{CASE REPORT}

A 60-year-old female patient admitted to the female general medicine ward with the complaints of chest pain since $6 \mathrm{pm}$, and she was apparently well 1 day back then given a history of chest pain since 6 pm which is a burning type of pain and also a history of breathlessness since $6 \mathrm{pm}$. The patient's appetite was reduced and sleep was disturbed. She is known case of (k/c/o) hypertension and diabetes mellitus since 5 years on mediations, i.e., tablet atenolol - $5 \mathrm{mg}$ (1-0-0), tablet amlodipine - 5 mg (1-0-0), and tablet metformin - $500 \mathrm{mg}(1-0-1)$.

On examination, the patient was conscious and oriented, the patient consent was received, and the patient's BP was $120 / 100 \mathrm{mmHg}$, pulse - 80 bpm, Sp02 - 94\% under room air, and RS-B/L coarse crepitation (+). The laboratory data are as follows:

a) Electrocardiogram: ST depression in II, V4, V5, and V6 with T-wave inversion suspected in the same lead, left ventricular strain pattern

b) USG: B/L Grade I renal parenchymal disease

c) Peripheral smear report: Normocytic hypochromic to microcytic picture with neutrophilia and thrombocytosis (Table 1).

On the assessment of both subjective and objective evidence, the patient was diagnosed as "acute left ventricular failure, ischemic heart disease with old hypertension, and type 2 diabetes mellitus."

The patient was treated with the following medications, It is the treatment when patient admitted in the hospital. Continuous BP was monitored on the $1^{\text {st }}, 2^{\text {nd }}$, and $3^{\text {rd }}$ days (Table 2). Day 2 examination shows pulse rate (PR) - 93 bpm, BP - 136/80 mmHg, and SpO2 - 96\% under room air; day 3 examination shows PR - 94 bpm, BP - 100/70 mmHg, and SpO2 - 97\% under room air; day 4 examination shows PR - 80 bpm and $\mathrm{BP}$ - 126/70 mmHg; day 5 examination shows PR - 76 bpm and $\mathrm{BP}-118 / 70 \mathrm{mmHg}$. 
Table 1: Laboratory data

\begin{tabular}{|c|c|c|c|c|c|c|}
\hline Parameter & Day 1 & Day 2 & Day 3 & Day 4 & Day 5 & Day 6 \\
\hline WBC & 36,300 & 33,300 & & 26,500 & 24,400 & 11,000 \\
\hline Polymorphs & $60 \%$ & $89 \%$ & & $88 \%$ & $88 \%$ & $75 \%$ \\
\hline Lymphocytes & $38 \%$ & $06 \%$ & & $11 \%$ & $12 \%$ & $25 \%$ \\
\hline Platelets & $7.58 \mathrm{~L} /$ cumm & $6.74 \mathrm{~L} /$ cumm & & $6.46 \mathrm{~L} /$ cumm & $6.21 \mathrm{~L} /$ cumm & $6 \mathrm{~L} /$ cumm \\
\hline MCV & $74 \mathrm{fl}$ & $83.7 \mathrm{fl}$ & & $75 \mathrm{fl}$ & $74 \mathrm{fl}$ & $74.2 \mathrm{fl}$ \\
\hline $\mathrm{MCH}$ & $26 \mathrm{pg} /$ cells & $26.7 \mathrm{pg} / \mathrm{cells}$ & & 25.6 pg/cells & $25.4 \mathrm{pg} / \mathrm{cells}$ & $25.2 \mathrm{pg} / \mathrm{c}$ \\
\hline $\mathrm{MCHC}$ & $35 \mathrm{~g} / \mathrm{dl}$ & $34.9 \mathrm{~g} / \mathrm{dl}$ & & $34.1 \mathrm{~g} / \mathrm{dl}$ & $34.0 \mathrm{~g} / \mathrm{dl}$ & $33.2 \mathrm{~g} / \mathrm{dl}$ \\
\hline Potassium & $3.6 \mathrm{mEq} / \mathrm{L}$ & $6.0 \mathrm{mEq} / \mathrm{L}$ & $3.5 \mathrm{mEq} / \mathrm{L}$ & $5.8 \mathrm{mEq} / \mathrm{L}$ & $5.3 \mathrm{mEq} / \mathrm{L}$ & \\
\hline Chloride & $100 \mathrm{mEq} / \mathrm{L}$ & $81 \mathrm{mEq} / \mathrm{L}$ & $102 \mathrm{mEq} / \mathrm{L}$ & $84 \mathrm{mEq} / \mathrm{L}$ & $87 \mathrm{mEq} / \mathrm{L}$ & \\
\hline Serum creatinine & $1.6 \mathrm{mg} / \mathrm{dl}$ & $1.7 \mathrm{mg} / \mathrm{dl}$ & $1.7 \mathrm{mg} / \mathrm{dl}$ & $1.6 \mathrm{mg} / \mathrm{dl}$ & $1.6 \mathrm{mg} / \mathrm{dl}$ & $1.6 \mathrm{mg} / \mathrm{dl}$ \\
\hline Serum urea & $55 \mathrm{mg} / \mathrm{dl}$ & $64 \mathrm{mg} / \mathrm{dl}$ & $67 \mathrm{mg} / \mathrm{dl}$ & $55 \mathrm{mg} / \mathrm{dl}$ & $32 \mathrm{mg} / \mathrm{dl}$ & $50 \mathrm{mg} / \mathrm{dl}$ \\
\hline
\end{tabular}

WBC: White blood cell, MCH: Mean corpuscular hemoglobin, MCV: Mean corpuscular volume, MCHC: Mean corpuscular hemoglobin concentration

\section{DISCUSSION}

Various large epidemiological studies and meta-analyses of clinical studies have been conducted to assess the effects of NSAIDs on $\mathrm{BP}$ in patients taking antihypertensive. A cross-sectional cohort study (1993) conducted in 2800 elderly patients those taking both NSAIDs and antihypertensive has shown $29 \%$ increased risk of hypertension than those taking antihypertensives [1]. Furosemide has been used as an effort to try to minimize the risk of contrastinduced nephropathy. Although the results for the studies showing that furosemide use for the prevention of acute kidney injury (AKI) is inconclusive [3], Marenzi et al. in a prospective randomized trial showed a significantly lower incidence of AKI in patients treated with hydration and furosemide versus those treated with hydration alone [4]. In our study, the patient was diagnosed with "acute LV failure, ischemic heart disease with old hypertension, and type 2 diabetes mellitus." She had been treated with aspirin, clopidogrel, atorvastatin, furosemide, nitroglycerin, pantoprazole, heparin, insulin R, enalapril, amlodipine, and calcium gluconate and nebulizer asthalin. There are 6 major interactions, of which 4 moderate interactions have been found among the prescribed drugs using Micromedex software.

\section{Major interactions}

a) Amlodipine $\Leftrightarrow$ Clopidogrel: Concurrent use of amlodipine and clopidogrel may result in decreased antiplatelet effect and increased risk of thrombotic events.

b) Aspirin $\Leftrightarrow$ Furosemide: Concurrent use of loop diuretics and NSAIDs may result in reduced diuretic effectiveness and possible nephrotoxicity

c) Clopidogrel $\Leftrightarrow$ Aspirin: Concurrent use of aspirin and clopidogrel may result in an increased risk of bleeding.

d) Clopidogrel $\Leftrightarrow$ Heparin: Concurrent use of anticoagulants and antiplatelet agents may result in increased risk of bleeding.

e) Heparin $\Leftrightarrow$ Aspirin: Concurrent use of anticoagulants and antiplatelet agents may result in increased risk of bleeding.

f) Nitroglycerin $\Leftrightarrow$ Heparin: Concurrent use of heparin and nitroglycerin may result in a decreased partial thromboplastin time.

\section{Moderate interactions}

a) Nitroglycerin $\Leftrightarrow$ Aspirin: Concurrent use of aspirin and nitroglycerin may result in an increased in nitroglycerin concentrations and additive platelet function depression.

b) Aspirin $\Leftrightarrow$ Insulin R: Concurrent use of insulin/pramlintide and salicylates may result in increased risk of hypoglycemia.

c) Enalapril $\Leftrightarrow$ Insulin: Concurrent use of ACE inhibitors and antidiabetic agents may result in increased risk of hypoglycemia.

d) Enalapril $\Leftrightarrow$ Furosemide: Concurrent use of ACE inhibitors and loop diuretics may result in postural hypotension [5].

The patient was taking aspirin and furosemide all the 6 days of the treatment, and the concurrent use of these two drugs causes possible nephrotoxicity where the patient was diagnosed as Grade I
Table 2: Blood pressure monitoring chart

\begin{tabular}{|c|c|c|c|}
\hline Date & Time & Blood pressure & Pulse rate \\
\hline \multirow[t]{4}{*}{ September 02,18 (day 1 ) } & $8: 45 \mathrm{pm}$ & $180 / 90 \mathrm{mmHg}$ & $86 \mathrm{bpm}$ \\
\hline & $10: 00 \mathrm{pm}$ & $190 / 100 \mathrm{mmHg}$ & $80 \mathrm{bpm}$ \\
\hline & $2: 00 \mathrm{am}$ & $170 / 90 \mathrm{mmHg}$ & $84 \mathrm{bpm}$ \\
\hline & $5: 00 \mathrm{am}$ & $140 / 86 \mathrm{mmHg}$ & $84 \mathrm{bpm}$ \\
\hline \multirow[t]{5}{*}{ September 03, 18 (day 2) } & 8:00 am & $130 / 86 \mathrm{mmHg}$ & $82 \mathrm{bpm}$ \\
\hline & $9: 00 \mathrm{am}$ & $140 / 80 \mathrm{mmHg}$ & 82 bpm \\
\hline & $11: 00 \mathrm{am}$ & $130 / 86 \mathrm{mmHg}$ & 86 bpm \\
\hline & $2: 00 \mathrm{pm}$ & $140 / 80 \mathrm{mmHg}$ & $86 \mathrm{bpm}$ \\
\hline & $9: 00 \mathrm{pm}$ & $100 / 70 \mathrm{mmHg}$ & \\
\hline \multirow[t]{11}{*}{ September 04,18 (day 3 ) } & $10: 00 \mathrm{pm}$ & $106 / 70 \mathrm{mmHg}$ & \\
\hline & $11: 00 \mathrm{pm}$ & $110 / 70 \mathrm{mmHg}$ & \\
\hline & $12: 00 \mathrm{am}$ & $110 / 68 \mathrm{mmHg}$ & \\
\hline & $1: 00 \mathrm{am}$ & $106 / 70 \mathrm{mmHg}$ & \\
\hline & $2: 00 \mathrm{am}$ & $110 / 70 \mathrm{mmHg}$ & \\
\hline & 3:00 am & $106 / 70 \mathrm{mmHg}$ & \\
\hline & 4:00 am & $110 / 70 \mathrm{mmHg}$ & \\
\hline & $5: 00 \mathrm{am}$ & $100 / 70 \mathrm{mmHg}$ & \\
\hline & $6: 00 \mathrm{am}$ & $98 / 70 \mathrm{mmHg}$ & \\
\hline & 7:00 am & $98 / 66 \mathrm{mmHg}$ & \\
\hline & 8:00 am & $100 / 68 \mathrm{mmHg}$ & \\
\hline
\end{tabular}

renal parenchymal disease in the middle of the treatment, which was a suspected adverse drug interaction between the drugs. In addition, the progression of CKD may lead to the increased number of medications taken by patients to manage the complications and the comorbidities and subsequently increase the prevalence of Drug Related Problems (DRPs). DRP is defined as "an event occurring, as a result, the drug therapy that actually or potentially interferes with desired health outcomes" [6]. The leading factors of kidney failure are undiagnosed or uncontrolled BP, diabetes mellitus, irrational use of painkillers, improper diet, and environmental stress. According to recently carried out clinical studies, earlier diagnosis and treatment of hypertensive patients with incipient renal failure could result in more effective control of BP and therefore earlier detection and treatment of atheromatous progression toward end-stage renal disease [7]. Even the patient was given tablet enalapril $2.5 \mathrm{mg}$ orally for two times, i.e., on the $2^{\text {nd }}$ and $3^{\text {rd }}$ days and stopped on the $4^{\text {th }}$ day due to decrease of BP, and after stopping the drug, the patient's BP ( $5^{\text {th }}$ day) has improved to $126 / 70 \mathrm{mmHg}$ from $98 / 66 \mathrm{mmHg}$ and $100 / 68 \mathrm{mmHg}$. A study in healthy subjects given single doses of enalapril and furosemide found no evidence of any pharmacokinetic interaction between these drugs. The risk of first-dose hypotension can be reduced by starting low dose of ACE inhibitors. In a study, 8 patients with hypertension who had been taking a diuretic (mainly furosemide or hydrochlorothiazide) for at least 4 weeks, captopril was started in small, increasing doses, from $6.25 \mathrm{mg}$. Symptomatic postural hypotension was seen in 2 of the 8 patients, but it was mild and transient [1]. 


\section{CONCLUSION}

Aspirin may compete with furosemide for a common secretory mechanism in the proximal tubule. In addition, aspirin may also inhibit renal prostaglandins which appear to mediate the increased renal blood flow induced by loop diuretics in cirrhotic with ascites. An interaction between aspirin and loop diuretics, which results in an attenuation of the diuretic effect, is established; however, the clinical relevance of this effect does not appear to have been studied. Nevertheless, the reduction in diuretic effects seen in the studies might reasonably be expected to lead to a worsening of the condition being treated with the loop diuretic. The UK manufacturer of furosemide warns that aspirin may attenuate the action of furosemide and may cause acute renal failure in cases of pre-existing hypovolemia or dehydration. It would, therefore, seem prudent to avoid the use of high-dose salicylates in those taking loop diuretics, giving an alternative non-NSAID analgesic wherever possible. Close monitoring of signs of reduced diuretic effect and signs of renal impairment is necessary in case of concurrent administration of aspirin and furosemide. In such cases, either reconsidering use of salicylate or diuretic dose adjustment is suggested [1].

\section{ACKNOWLEDGMENT}

The authors express sincere gratefulness to Principal Dr. Manjunath. V. Jali and Dr. H. N. Girish, Head of the Department of TVM College of Pharmacy, Ballari, for giving an opportunity to do this project.

\section{AUTHORS' CONTRIBUTIONS}

Gundeti Kavya Reddy: Concept, informed consent, laboratory investigations, laboratory report interpretation, patient evaluation, examination of patients on follow-up, drafting final report, and publication.

Nisi Grace Kuriakose: Concept, design, master file of project and evaluating patients' file, laboratory investigations, laboratory report interpretation, drafting final report, and publication.

\section{CONFLICTS OF INTEREST}

The authors declare that they have no conflicts of interest.

\section{REFERENCES}

1. Baxter K, Preston CL. Stockley's Drug Interactions. $10^{\text {th }}$ ed. London: Pharmaceutical Press; 2013. p. 1028-9, 943, 27.

2. Tripathi KD. Essentialsof Medical Pharmacology. $7^{\text {th }}$ ed. New Delhi: Jaypee Group; 2013. p. 559-60,195-198.

3. Marenzi G, Ferrari C, Marana I, Assanelli E, De Metrio M, Teruzzi G, et al. Prevention of contrast nephropathy by furosemide with matched hydration: The MYTHOS (Induced diuresis with matched hydration compared to standard hydration for contrast induced nephropathy prevention) trial. JACC Cardiovase Interv 2012;5:90-7.

4. Ahmed US, Iqbal HI, Akbar SR. Furosemidein acute kidney injury a vexed issue. Austin J of Nephrol Hypertens 2014;1:2.

5. Aspirin, Furosemide. In: Interaction Checking [Database on the Internet]. Greenwood Village [CO]: Truven Health Analytics; 2018 Available from: http://www.micromedexsolutions.com.Subscription required to view. [Last accessed on 2018 Oct 08 ]

6. Ramadaniati HU, Anggriani Y, Wowor VM, Rianti A. Drug-related problem sinchronic kidneys disease patients in an Indonesian hospital: do the problems really matter ? Int J Pharm Pharm Sci 2016;8:298-302.

7. Saeed F, Ahmad M, Alam SM, Praveena K. Chronic kidney disease a multi-center study in Karachi, Pakistan. Int J Pharm Pharm Sci 2017;9:170-4 